\title{
Analisis Perbandingan KNN dengan SVM untuk Klasifikasi Penyakit Diabetes Retinopati berdasarkan Citra Eksudat dan Mikroaneurisma
}

\author{
SUCI AULIA, SUGONDO HADIYOSO, DADAN NUR RAMADAN \\ Program Studi D3 Teknik Telekomunikasi Fakultas Ilmu Terapan \\ Telkom University
}

sucia@tass.telkomuniversity.ac.id

\begin{abstract}
ABSTRAK
Penelitian mengenai pengklasifikasian tingkat keparahan penyakit Diabetes Retinopati berbasis image processing masih hangat dibicarakan, citra yang biasa digunakan untuk mendeteksi jenis penyakit ini adalah citra optik disk, mikroaneurisma, eksudat, dan hemorrhages yang berasal dari citra fundus. Pada penelitian ini telah dilakukan perbandingan algoritma SVM dengan KNN untuk klasifikasi penyakit diabetes retinopati (mild, moderate, severe) berdasarkan citra eksudat dan microaneurisma. Untuk proses ekstraksi ciri digunakan metode wavelet pada masing-masing kedua metode tersebut. Pada penelitian ini digunakan 160 data uji, masing-masing 40 citra untuk kelas normal, kelas mild, kelas moderate, kelas saviere. Tingkat akurasi yang diperoleh dengan menggunakan metode KNN lebih tinggi dibandingkan SVM, yaitu $65 \%$ dan 62\%. Klasifikasi dengan algoritma KNN diperoleh hasil terbaik dengan parameter $K=9$ cityblock. Sedangkan klasifikasi dengan metode SVM diperoleh hasil terbaik dengan parameter One Agains All.
\end{abstract}

Kata Kunci : Diabetic Retinopathy, KNN, SVM, Wavelet.

\begin{abstract}
Research based on severity classification of the disease diabetic retinopathy by using image processing method is still hotly debated, the image is used to detect the type of this disease is an optical image of the disk, microaneurysm, exudates, and bleeding of the image of the fundus. This study was performed to compare SVM method with KNN method for classification of diabetic retinopathy disease (mild, moderate, severe) based on exudate and microaneurysm image. For feature extraction uses wavelet method, and each of the two methods. This study made use of 160 test data, each of 40 images for normal class, mild class, moderate class, severe class. The accuracy obtained by KNN higher than SVM, with 65\% and 62\%. KNN classification method achieved the best results with the parameters $K=9$, cityblock. While the classification with SVM method obtained the best results with parameters One agains all .
\end{abstract}

Keywords : Diabetic Retinopathy, KNN, SVM, Wavelet. 


\section{PENDAHULUAN}

Penelitian untuk mendeteksi penyakit Diabetic Retinopathy (DR) berdasarkan klasifikasi jenisnya (mild, moderate, severe) telah banyak dilakukan, diantaranya adalah penelitian "Simulasi Untuk Klasifikasi Retinopati Diabetes Nonproliferatif Berdasarkan Mikroaneurisma dan Hemorrhages" (Zahara, 2011), yaitu klasifikasi jenis penyakit DR menggunakan citra optik disk, eksudat, dan microaneurisma berbasis basic image processing dengan tingkat akurasi $64 \%$. Penelitian lainnya yaitu, deteksi penyakit diabetes retinopati dengan exudate sebagai parameter dengan menggunakan transformasi wavelet untuk segmentasi citra dan menggunakan algoritma jaringan saraf tiruan untuk mengklasifikasi.Dengan metode tersebut diperoleh tingkat akurasi sebesar 90\% (Riliadi,2013), tetapi pada penelitian ini hanya mendeteksi retina normal dan retinopati diabetes tanpa ada klasifikasi lain .

Pada penelitian ini, citra fundus yang digunakan untuk klasifikasi DR tidak hanya citra mikroaneurisma saja tetapi juga menggunakan citra eksudat, namun citra optik disk nya dihilangkan terlebih dahulu dengan preprosesing. Metode yang digunakan untuk klasisfikasi DR adalah SVM (Support Vector Machines), SVM merupakan machine learning algorithm yang sering dipakai untuk proses klasifikasi karena dapat dengan mudah untuk diimplementasikan dan secara umum memiliki performansi yang baik dibidang pattern recognition. Selain SVM, digunakan juga metode KNN sebagai pembandingnya. Rajpoot (Rajpoot, 2004) telah melakukan penelitian untuk pengklasifikasian tekstur menggunakan Wavelet dan Support Vector Machines dengan rata-rata error 7.6\%. Berdasarkan pada referensi tersebut, maka pada penelitian ini digunakan wavelet pada proses ekstraksi ciri baik untuk klasifikasi dengan SVM maupun KNN.

Citra fundus yang yang digunakan pada penelitian ini diperoleh dari Rumah Sakit Mata Cicendo Bandung, sebanyak 100 citra. Dari 100 citra tersebut, 60 citra dipakai untuk citra latih dan 40 citra untuk citra uji. Setiap citra telah diberikan kategori (kelas normal, DR mild, DR moderate, dan DR severe) oleh dokter spesialis mata.

\subsection{Diabetic Retinopathy}

Retinopati diabetes adalah suatu mikroangiopati progresif yang ditandai oleh kerusakan dan sumbatan pada pembuluh darah halus retina. Kelainan patologik yang paling dini adalah penebalan membran basal endotel kapiler dan penurunan jumlah perisit(Tjandrasa, 2013) . Secara umum klasifikasi retinopati diabetes dibagi menjadi 2, yaitu Non-Proliferatif Diabetic Retinopathy (NPDR), dan Preproliferatif Diabetic Retinopathy (PDR). NPDR Adalah stage awal dari diabetes retinopati, pada stage ini, pembulu darah kecil pada retina mengalami pendarahan atau bocor, cairan yang bocor ini menyebabkan retina membengkak dan membentuk gumpalan-gumpalan atau exudate.Ada tiga klasifikasi dari NPDR (Santosa, 2005) seperti yang diperlihatkan pada Gambar 1, yaitu:

a) Mild NPDR : Paling tidak terdapat satu mikroaneurisma dan pendarahan karena pembulu darah pada retina pecah. Pada tahap ini pasien disarankan menemui dokter mata secara rutin sekurang-kurangnya 1 kali setahun.

b) Moderate NPDR : Hemorrhages dan mikroaneurisma berada paling tidak di satu kuadran yang sama. Jumlah mikroaneurisma semakin banyak, lebih banyak dibandingkan dengan Mild NPDR.

c) Severe NPDR : Jika mikroanerisma dan intraretinal hemorrhages semuanya berada diempat kuadran yang sama. 

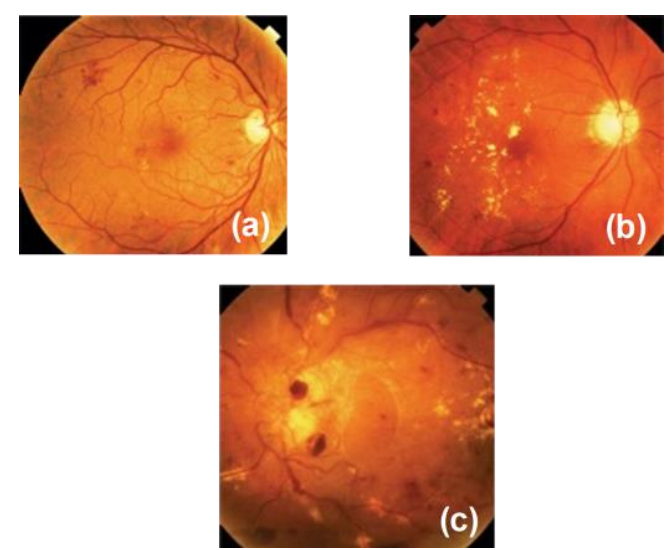

\section{Gambar 1. Citra Retina (a) Mild NPDR (b) Moderate NPDR (c) Severe NPDR (Rajpoot, 2004)}

Pada penelitian ini, tipe non-proliferatif ditandai dengan munculnya:

\section{a. Mikroaneurisma}

Mikroaneurisma adalah penonjolan dinding kapiler berbentuk gelembung, disebabkan oleh kelemahan dinding kapiler, sebagai akibat dari hilangnya sel perisit. Ukuran mikroaneursma berkisar antara $12-100 \mu$, terdapat disisi kapiler berwarna kekuningan.

b. Exudate

Exudate atau lemak lemak protein dibagi menjadi dua, yaitu:

1. Hard Exudate, berwarna kuning karena eksudasi plasma yang lama. Pada angiografi fluoresin tampak sebagai kebocoran flouresin diluar pembulu darah. Terutama terdiri dari lipid yang didapatkan pada hiperlipoproteinemia.

2. Cotton Wool patch, berwarna putih, tidak berbatas tegas, dihubungkan dengan iskemik retina.

\subsection{Support Vector Machines (SVM)}

SVM merupakan salah satu metode unggulan dibidang pattern recognition, sebagai algoritma yang terhitung masih baru (1992), SVM berkembang pesat karena berprinsip Structural Risk Minimization (SRM) dengan tujuan menemukan hyperplane terbaik untuk memisahkan dua buah kelas pada suatu space sehingga algoritma ini cocok untuk diimplementasikan sebagai clasificator .

Berbeda dengan strategi neural network yang berusaha mencari hyperplane pemisah antar class, SVM berusaha menemukan hyperplane yang terbaik pada input space. Prinsip dasar SVM adalah linear classifier, dan selanjutnya dikembangkan agar dapat bekerja pada problem non-linear. dengan memasukkan konsep kernel trick pada ruang kerja berdimensi tinggi .

Konsep SVM adalah mendesain sebuah hyperplane ${ }^{1}$ yang dapat mengklasifikasikan seluruh data training menjadi dua buah kelas, pada Gambar 2 memperlihatkan beberapa pattern yang merupakan anggota dari dua buah class yang berbentuk lingkaran dan kotak. Berbagai alternatif garis pemisah (discrimination boundaries) ditunjukkan pada Gambar 3. 


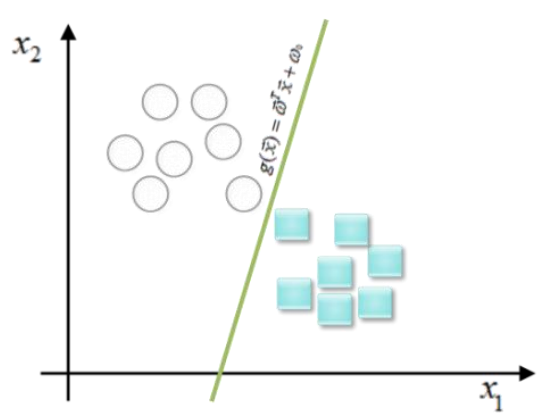

Gambar 2. Hyperplane mengklasifikasikan data menjadi dua kelas.

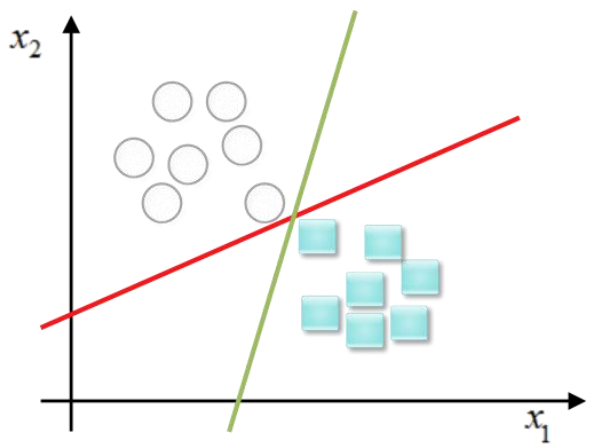

Gambar 3. Mencari hyperplane pemisah terbaik antar kelas.

Hyperplane terbaik antara kedua class dapat ditemukan dengan cara mengukur margin hyperplane tersebut dan mencari titik maksimalnya. Margin adalah jarak antara hyperplane dengan pattern terdekat dari masing-masing kelas, seperti yang terlihat pada Gambar 4. Pattern yang paling dekat ini disebut sebagai support vector.

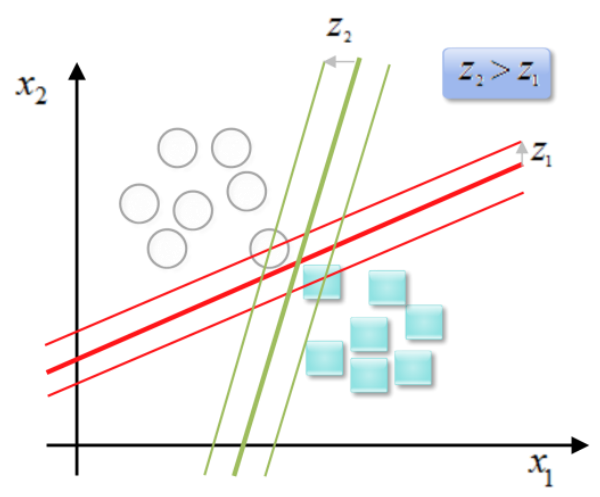

Gambar 4. Support vector, jarak terdekat dengan masing-masing kelas.

Garis solid hijau pada Gambar 5 menunjukkan hyperplane yang terbaik, yaitu yang terletak tepat pada tengah-tengah kedua kelas, sedangkan lingkaran dan kotak yang berada dalam margin $Z_{2}$ disebut sebagai support vector. Usaha untuk mencari lokasi hyperplane ini merupakan inti dari proses pembelajaran pada SVM.

${ }_{1}^{1}$ hyperplane dalam ruang vector berdimensi $d$ adalah affine subspace berdimensi $d$-1 yang membagi ruang vector tersebut ke dalam dua bagian, yang masing-masing berkorespondensi pada class yang berbeda (Riliadi,2013) 


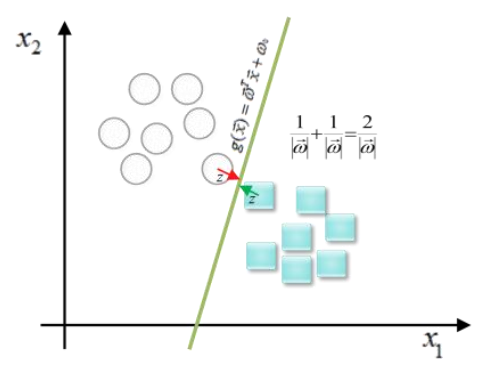

\section{Gambar 5. Hyperplane terbaik garis bewarna hijau.}

Dataset pelatihan didefinisikan sebagai:

dengan;

$$
X 1 \in R p
$$

$$
Y 1 \in\{-1,+1\}, i=1, \ldots, n
$$

Fungsi hyperplane didefinisikan dengan persamaan:

$$
\begin{aligned}
& f(x)=w x+b=0 \\
& W=(w 1, w 2, w 3, \ldots, w p)
\end{aligned}
$$

$\mathrm{w}$ adalah bobot vektor hyperplane dan $\mathrm{b}=$ mendefinisikan bias.

Agar margin menjadi maksimal maka digunakan persamaan optimasi SVM untuk kasus klasifikasi linear di dalam primal space, yaitu:

$$
\text { dengan } \begin{aligned}
& \min \frac{1}{2}\|w\|^{2} \\
& y 1(b+w x i) \geq 1, i=1, \ldots, n
\end{aligned}
$$

Sedangkan untuk kasus non-linear dipisahkan dengan konsep soft margin yang diperkenalkan di SVM (Cristianini, 2000). Konsep Soft margin SVM adalah meminimalkan kesalahan klasifikasi (misclassification error) dengan memperkenalkan slack variable.

$$
\varepsilon_{i} \geq 0, i=1, \ldots, n \text {. }
$$

Seperti yang diperlihatkan pada Gambar 6:

1. Nilai variabel slack untuk data klasifikasi yang benar adalah $\varepsilon_{i}=0$.

2. Nilai variabel slack untuk data, ada diantara margin $0 \leq \varepsilon_{i} \leq 1$.

3. Untuk data klasifikasi yang salah, nilai variabel slacknya adalah $\varepsilon_{i}=1$.

4. Jumlah nilai yang error (variabel slack) dikalikan dengan C.

Nilai C berdasarkan trade-off antara margin maksimum dan error yang dapat ditoleransi. Dengan konsep softmargin SVM optimasi dibuat persamaan berikut :

$$
\tau(w)=\frac{1}{2}\|w\|^{2}+C \sum_{i=1}^{n} \varepsilon_{i}
$$


Dimana :

$$
\begin{gathered}
\varepsilon_{i} \geq 0 \\
y_{i}\left(b+w x_{i}\right) \geq 1-\varepsilon_{i}, i=1, \ldots, n
\end{gathered}
$$

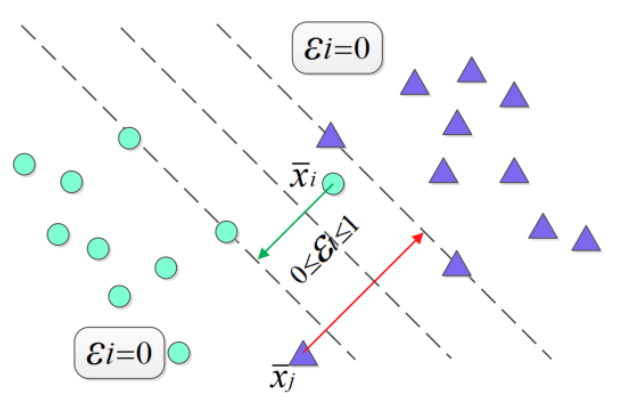

Gambar 6. SVM dengan variabel slack

Problem optimasi diselesaikan dengan mengenalkan fungsi Lagrangian. Dengan kondisi ketika;

$$
\alpha_{i} \geq 0, i=1, \ldots, n
$$

maka persamaannya adalah,

$$
w=\sum_{i=1}^{n} \propto_{i} y_{i} x_{i}
$$

Sedangkan ketika kondisi support vector data ada di $\alpha_{i}>0$, nilai b diganti dengan;

$$
\begin{gathered}
\left(b+\left(w \cdot x_{i}\right)\right)=y_{i}\left(1-\varepsilon_{i}\right) \\
b=y_{i} \cdot\left(1-\varepsilon_{i}\right)-\left(w \cdot x_{i}\right)
\end{gathered}
$$

\subsection{KNN}

KNN merupakan algoritma paling sederhana diantara algoritma lainnya dalam hal memprediksikan suatu kelas pada suatu sampel. Untuk mengklasifikasikan suatu kelas, KNN bekerja berdasarkan jarak terdekat ketetanggaan antar objek dengan cara sebagai berikut (Sudha, 2012) :

1. Menghitung jarak dari seluruh training vectors to test vectors.

2. Ambil nilai $\mathrm{K}$ yang paling dekat nilai vektornya.

3. Hitung nilai rata-ratanya.

Jika nilai $\mathrm{k}=1$, maka objek diasumsikan sebagai anggota kelas dari tetangga terdekatnya. Nilai $k$ terbaik tergantung dari banyaknya data. Secara umum semakin tinggi nilai k makan akan mengurangi pengaruh noise pada proses klasifikasi.Untuk menghitung jarak pada seluruh data latih, pengukurannya dapat dilakukkan dengan beberapa metoda seperti Euclidean distance, Cityblock distance, Cosine distance, Correlation, Hamming distance.

\subsection{Haar Wavelet}

Trasformasi dari 2D Haar wavelet dapat dilihat dari contoh matriks $4 \times 4$ seperti yang ditunjukkan pada Gambar 7 berikut. 
Analisis Perbandingan KNN Dengan SVM Untuk Klasifikasi Penyakit Diabetes Retinopati Berdasarkan

Citra Eksudat Dan Mikroaneurisma

$$
\left[\begin{array}{cccc}
30 & 16 & 51 & 24 \\
38 & 19 & 11 & 6 \\
28 & 45 & 53 & 5 \\
29 & 44 & 52 & 59
\end{array}\right]
$$

\section{Gambar 7. Matriks array 2D}

Kemudian dihitung jumlah rata-rata dan selisih setiap baris dan kolomnya, langkah pertama adalah menghitung nilai rata-rata dan selisih setiap baris.

Menghitung rata-rata baris ke-1

$$
\frac{30+16}{2}=23, \frac{51+24}{2}=37.5
$$

Selisih baris ke-1 : $30-23=7$, dan $51-37.5=13.5$

Maka hasil trasformasi baris ke-1 menjadi : [23 37.57 13.5]

Kemudian lakukan operasi yang sama pada nilai rata-rata : [23 37.5]

maka hasil akhir transformasi baris ke-1 menjadi: [30.35 -7.25 7 13.5]

Matriks baru hasil dari transformasi setiap baris dapat dilihat pada Gambar 8 berikut.

$$
\left[\begin{array}{cccc}
30,5 & -7,25 & 7 & 13,5 \\
18,5 & 10 & 9,5 & 2,5 \\
32,75 & 3,75 & -8,5 & 24 \\
46 & -9,5 & -7,5 & -3.5
\end{array}\right]
$$

Gambar 8. Matriks hasil transformasi baris dari matriks array 2D gambar 7.

Kemudian dilakukan juga operasi yang sama untuk setiap kolom, sehingga diperoleh hasil akhir transformasi seperti pada gambar 9.

$$
\left[\begin{array}{cccc}
31,25 & 31 & 41,75 & 23,5 \\
2,75 & -13,5 & -10,75 & -8,5 \\
-4 & -1,5 & 20 & 9 \\
-0,5 & 0,5 & 0,5 & -27
\end{array}\right]
$$

Gambar 9. Matriks hasil transformasi kolom dari matriks array 2D gambar 8.

Dari matriks tersebut, matriks asli dapat direkonstruksi kembali dengan menggunakan operasi reverse dari rata-rata dan nilai selisihnya. Oleh karena itu Haar Wavelet ini mentransformasikan suatu input dengan sifat loss of information. 


\section{METODOLOGI PENELITIAN}

Tujuan dari penelitian ini adalah mengimplementasikan dan menganalisis metode SVM dan KNN untuk menentukan klasifikasi penyakit retinopati diabetes melalui ciri yang ada pada retina. Maka untuk mencapai tujuan tersebut, langkah-langkah metodologi penelitian yang dilakukan adalah sebagai berikut :

1. Pencarian referensi meliputi studi pustaka tentang:

a. Pengolahan citra digital (preprocessing, segmentasi citra)

b. Metode Haar Wavelet

c. Algoritma Support Vector Machine

d. Algoritma KNN

e. Penyakit Retinopati Diabetes Non Proliferatif

2. Pengumpulan data

Bertujuan untuk mendapatkan data citra yang akan menjadi input dalam sistem. Data didapat dari Rumah Sakit Mata Cicendo Bandung dan Klinik Spesialis Mata Netra.

3. Implementasi perangkat lunak

Sistem dirancang dengan menggunakan Matlab R2012b.

4. Analisis performansi

Melakukan analisis performansi pengidentifikasian penyakit retinopati diabetes menggunakan citra retina berdasarkan mikroneurisma dan eksudat.

5. Membandingan Metode

Membandingan metode mana yang paling baik untuk melakukan klasifikasi penyakit retinopati diabetes

6. Mengambil kesimpulan.

Mengambil kesimpulan setelah melakukan pengujian klasifikasi retinopati diabetes nonproliferatif.

\section{HASIL DAN DISKUSI}

\subsection{Deteksi Mikroaneurisma Dan Eksudat}

Berikut adalah langkah-langkah untuk mendeteksi mikroaneurisma dan eksudat pada input citra fundus :

\subsubsection{Deteksi Mikroaneurisma}

\section{A. Preprosesing:}

Pada proses ini yang dilakukan adalah mengubah warna citra input (diambil hanya layer-2 saja dari $R G B$ ) ke Grayscale untuk mempermudah proses deteksi mikroaneurisma

B. Adaptif histogram ekualisasi :

Adaptif histogram ekualisasi dilakukan untuk memperjelas mikroaneurisma yang berada didekat pembuluh darah. Hasilnya dapat dilihat pada Gambar 10. 


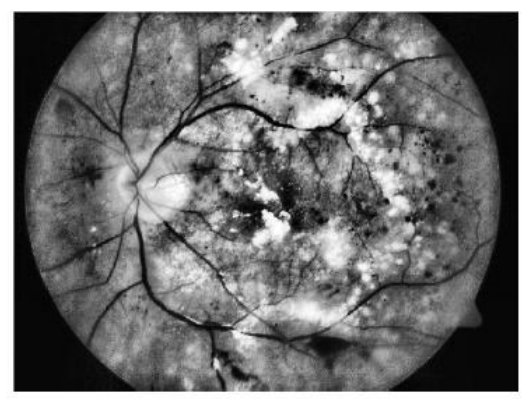

\section{Gambar 10. Citra fundus hasil adaptif histogram ekualisasi}

C. Canny edge detection:

Selanjutnya dilakukan deteksi tepi dengan canny pada citra hasil ekualisasi adaptif histogram, seperti yang terlihat pada Gambar 11. Pada proses ini, nilai threshold diatur agar optic disc hilang.

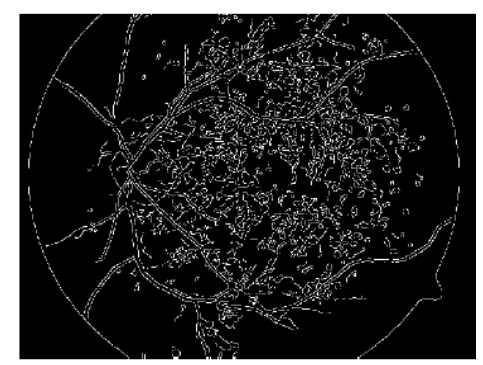

Gambar 11. Citra setelah dilakukan deteksi tepi dengan canny

D. Filling:

Hasil dari filling dapat dilihat pada Gambar 12, proses yang terjadi adalah penebalan pada calon mikroaneurisma kemudian dikurangkan hasilnya dengan citra hasil deteksi tepi sehingga diperoleh citra yang hanya terdapat mikroaneurisma saja.
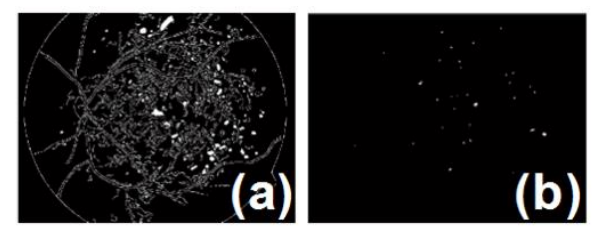

\section{Gambar 12. (a) Citra setelah di filling (b) mikroaneurisma}

\subsubsection{Deteksi Eksudat}

Dengan langkah yang sama pada proses deteksi mikroaneurisma, diperoleh citra biner yang hanya terdiri dari eksudat saja seperti Gambar 13 berikut.

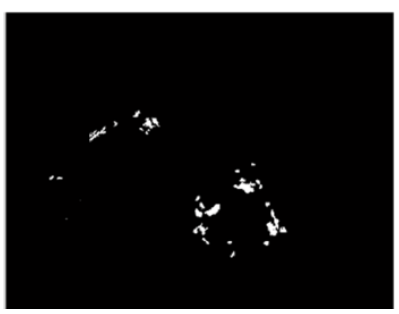

Gambar 13. Citra setelah optik disk dihilangkan

Jurnal ELKOMIKA Itenas - 83 


\subsection{Haar Wavelet Dan Ekstraksi Ciri}

Gabungan dari citra biner mikroaneurisma dan eksudat, yaitu gambar 11 dan gambar 12 akan menjadi masukan dalam proses dekomposisi, citra akan didekomposisi dengan menggunakan transformasi haar wavelet dari level 1 hingga level 7. Selanjutnya citra akan diekstrak dengan metode ekstraksi ciri statistik orde pertama mean dan variance, ciri latih akan disimpan untuk menjadi perbandingan ciri citra latih pada tahap selanjutnya. Citra latih terdiri dari 60 buah citra fundus, dimana masing-masing kelas (normal, mild, moderate, severe) memiliki 15 citra.

\subsection{Klasifikasi DR}

Pada penelitian ini, proses klasifikasi dilakukan dengan menggunakan algoritma SVM One Versus One (OVO) dan One Versus All (OVA) dan algoritma KNN (cosine, cityblock, euclidean dan correlation) sebagai pembandingnya.

\subsubsection{Klasifikasi dengan SVM}

Tabel 1 menunjukkan hasil pengujian dari proses klasifikasi menggunakan metoda SVM .

Tabel 1. Tingkat Akurasi Dengan Metoda Statistik Ekstraksi Ciri Mean

\begin{tabular}{|c|c|c|}
\hline $\begin{array}{c}\text { Wavelet } \\
\text { Level }\end{array}$ & $\begin{array}{c}\text { OVO } \\
(\mathbf{\%})\end{array}$ & $\begin{array}{c}\text { OVA } \\
(\mathbf{\%})\end{array}$ \\
\hline $\mathbf{1}$ & 16 & 48 \\
\hline $\mathbf{2}$ & 24 & 56 \\
\hline $\mathbf{3}$ & 34 & 62 \\
\hline $\mathbf{4}$ & 24 & 56 \\
\hline $\mathbf{5}$ & 20 & 48 \\
\hline $\mathbf{6}$ & 20 & 42 \\
\hline $\mathbf{7}$ & 48 & 40 \\
\hline
\end{tabular}

Dari Tabel 1, dengan menggunakan ciri statistik mean diperoleh tingkat akurasi maksimum $62 \%$, nilai tersebut diperoleh pada saat SVM menggunakan metode one versus all dengan parameter wavelet pada level 3.

Tabel 2. Tingkat Akurasi Dengan Metoda Statistik Ekstraksi Ciri Variance

\begin{tabular}{|c|c|c|}
\hline $\begin{array}{c}\text { Wavelet } \\
\text { Level }\end{array}$ & $\begin{array}{c}\text { OVO } \\
(\mathbf{\%})\end{array}$ & $\begin{array}{c}\text { OVA } \\
(\mathbf{\%})\end{array}$ \\
\hline $\mathbf{1}$ & 24 & 34 \\
\hline $\mathbf{2}$ & 24 & 38 \\
\hline $\mathbf{3}$ & 20 & 38 \\
\hline $\mathbf{4}$ & 28 & 32 \\
\hline $\mathbf{5}$ & 40 & 34 \\
\hline $\mathbf{6}$ & 56 & 50 \\
\hline $\mathbf{7}$ & 34 & 44 \\
\hline
\end{tabular}

Dari Tabel 2, dengan menggunakan ciri statistik varian diperoleh tingkat akurasi maksimum $56 \%$, nilai tersebut diperoleh pada saat SVM menggunakan metode one versus one dengan parameter wavelet pada level 6. 


\subsubsection{Klasifikasi dengan KNN}

Tabel 3. Tingkat Akurasi Algoritma KNN Ciri Statistik Mean Dengan Cosine Distance

\begin{tabular}{|c|c|c|c|c|c|}
\hline \multicolumn{6}{|c|}{ Cosine } \\
\hline \multirow{2}{*}{$\begin{array}{c}\text { Wavelet } \\
\text { Level }\end{array}$} & \multicolumn{5}{|c|}{ K } \\
\hline & 1 & 3 & 5 & 7 & 9 \\
\hline 1 & 35 & 32,5 & 22,5 & 32,5 & 27,5 \\
\hline 2 & 37,5 & 20 & 20 & 32,5 & 27,5 \\
\hline 3 & 42,5 & 30 & 25 & 37,5 & 27,5 \\
\hline 4 & 40 & 32,5 & 32,5 & 27,5 & 25 \\
\hline 5 & 37,5 & 27,5 & 35 & 35 & 32,5 \\
\hline 6 & 35 & 32,5 & 35 & 30 & 25 \\
\hline 7 & 40 & 42,5 & 35 & 32,5 & 30 \\
\hline
\end{tabular}

Dari Tabel 3 dengan menggunakan cosine distance diperoleh nilai maksimum $42.5 \%$ pada wavelet level 3 dan $\mathrm{k}=9$

Tabel 4. Tingkat Akurasi Algoritma KNN Ciri Statistik Mean Dengan Cityblok Distance

\begin{tabular}{|c|c|c|c|c|c|}
\hline \multicolumn{7}{|c|}{ Citiblock } \\
\hline \multirow{2}{*}{$\begin{array}{c}\text { Wavelet } \\
\text { Level }\end{array}$} & $\mathbf{1}$ & $\mathbf{3}$ & $\mathbf{5}$ & $\mathbf{7}$ & $\mathbf{9}$ \\
\hline $\mathbf{1}$ & 52,5 & 57,5 & 52,5 & 57,5 & 65 \\
\hline $\mathbf{2}$ & 42,5 & 50 & 45 & 60 & 57,5 \\
\hline $\mathbf{3}$ & 40 & 47,5 & 47,5 & 42,5 & 47,5 \\
\hline $\mathbf{4}$ & 52,5 & 45 & 37,5 & 40 & 42,5 \\
\hline $\mathbf{5}$ & 55 & 45 & 47,5 & 27,5 & 35 \\
\hline $\mathbf{6}$ & 42,5 & 40 & 35 & 40 & 32,5 \\
\hline $\mathbf{7}$ & 35 & 35 & 35 & 37,5 & 35 \\
\hline
\end{tabular}

Dari Tabel 4 dengan menggunakan cityblok distance diperoleh nilai maksimum 65\% pada wavelet level 1 dan $\mathrm{k}=9$.

Tabel 5. Tingkat Akurasi Algoritma KNN Ciri Statistik Mean Dengan Euclidean Distance

\begin{tabular}{|c|c|c|c|c|c|}
\hline \multicolumn{6}{|c|}{ Euclidean } \\
\hline \multirow{2}{*}{$\begin{array}{c}\text { Wavelet } \\
\text { Level }\end{array}$} & $\mathbf{5}$ & $\mathbf{3}$ & $\mathbf{5}$ & $\mathbf{7}$ & $\mathbf{9}$ \\
\cline { 2 - 6 } $\mathbf{1}$ & 50 & 57,5 & 52,5 & 62,5 & 62,5 \\
\hline $\mathbf{2}$ & 47,5 & 42,5 & 47,5 & 55 & 57,5 \\
\hline $\mathbf{3}$ & 60 & 47,5 & 47,5 & 47,5 & 50 \\
\hline $\mathbf{4}$ & 55 & 40 & 40 & 45 & 40 \\
\hline $\mathbf{5}$ & 52,5 & 45 & 35 & 32,5 & 37,5 \\
\hline $\mathbf{6}$ & 45 & 42,5 & 45 & 40 & 37,5 \\
\hline $\mathbf{7}$ & 37,5 & 40 & 40 & 32,5 & 35 \\
\hline
\end{tabular}


Dari Tabel 5 dengan menggunakan euclidean distance diperoleh nilai maksimum $62.5 \%$ pada wavelet level 1 dan $\mathrm{k}=9$.

Tabel 6. Tingkat Akurasi Algoritma KNN Ciri Statistik Mean Dengan Correlation Distance

\begin{tabular}{|c|c|c|c|c|c|}
\hline \multicolumn{6}{|c|}{ Correlation } \\
\hline \multirow{2}{*}{$\begin{array}{c}\text { Wavelet } \\
\text { Level }\end{array}$} & \multicolumn{5}{|c|}{ K } \\
\hline & 1 & 3 & 5 & 7 & 9 \\
\hline 1 & 37,5 & 45 & 42,5 & 32,5 & 30 \\
\hline 2 & 37,5 & 25 & 12,5 & 32,5 & 25 \\
\hline 3 & 40 & 30 & 27,5 & 27,5 & 30 \\
\hline 4 & 32,5 & 35 & 30 & 20 & 25 \\
\hline 5 & 37,5 & 30 & 35 & 37,5 & 25 \\
\hline 6 & 35 & 35 & 35 & 32,5 & 25 \\
\hline 7 & 40 & 42,5 & 35 & 32,5 & 30 \\
\hline
\end{tabular}

Dari Tabel 6 dengan menggunakan correlation distance diperoleh nilai maksimum 45\% pada wavelet level 1 dan $\mathrm{k}=3$.

Tabel 7. Tingkat akurasi algoritma KNN ciri statistik variance dengan cosine distance

\begin{tabular}{|c|c|c|c|c|c|}
\hline \multicolumn{6}{|c|}{ Cosine } \\
\hline \multirow{2}{*}{$\begin{array}{c}\text { Wavelet } \\
\text { Level }\end{array}$} & \multicolumn{5}{|c|}{$K$} \\
\hline & 1 & 3 & 5 & 7 & 9 \\
\hline 1 & 52,5 & 55 & 57,5 & 62,5 & 65 \\
\hline 2 & 52,5 & 45 & 42,5 & 52,5 & 47,5 \\
\hline 3 & 60 & 52,5 & 50 & 45 & 42,5 \\
\hline 4 & 55 & 37,5 & 20 & 37,5 & 32,5 \\
\hline 5 & 37,5 & 27,5 & 30 & 30 & 30 \\
\hline 6 & 42,5 & 40 & 32,5 & 30 & 37,5 \\
\hline 7 & 32,5 & 32,5 & 35 & 37,5 & 35 \\
\hline
\end{tabular}

Dari Tabel 7 dengan menggunakan cosine distance diperoleh nilai maksimum $65 \%$ pada wavelet level 1 dan $\mathrm{k}=9$.

Tabel 8. Tingkat Akurasi Algoritma KNN Ciri Statistik Variance Dengan Cityblock Distance

\begin{tabular}{|c|c|c|c|c|c|}
\hline \multicolumn{7}{|c|}{ Cityblock } \\
\hline \multirow{2}{*}{$\begin{array}{c}\text { Wavelet } \\
\text { Level }\end{array}$} & $\mathbf{1}$ & $\mathbf{3}$ & $\mathbf{5}$ & $\mathbf{7}$ & $\mathbf{9}$ \\
\hline $\mathbf{1}$ & 60 & 60 & 50 & 52,5 & 50 \\
\hline $\mathbf{2}$ & 47,5 & 50 & 50 & 50 & 37,5 \\
\hline $\mathbf{3}$ & 65 & 62,5 & 52,5 & 55 & 45 \\
\hline $\mathbf{4}$ & 52,5 & 40 & 22,5 & 35 & 32,5 \\
\hline $\mathbf{5}$ & 45 & 32,5 & 30 & 30 & 30 \\
\hline $\mathbf{6}$ & 37,5 & 27,5 & 30 & 30 & 30 \\
\hline $\mathbf{7}$ & 40 & 30 & 30 & 32,5 & 35 \\
\hline
\end{tabular}

Jurnal ELKOMIKA Itenas - 86 
Dari Tabel 8 dengan menggunakan cityblock distance diperoleh nilai maksimum 65\% pada wavelet level 3 dan $\mathrm{k}=1$.

Tabel 9. Tingkat Akurasi Algoritma KNN Ciri Statistik Variance Dengan Euclidean Distance

\begin{tabular}{|c|c|c|c|c|c|}
\hline \multicolumn{7}{|c|}{ Euclidean } \\
\hline Wavelet & \multicolumn{5}{|c|}{ K } \\
\cline { 2 - 6 } Level & $\mathbf{1}$ & $\mathbf{3}$ & $\mathbf{5}$ & $\mathbf{7}$ & $\mathbf{9}$ \\
\hline $\mathbf{1}$ & 57,5 & 55 & 50 & 50 & 45 \\
\hline $\mathbf{2}$ & 50 & 55 & 55 & 42,5 & 40 \\
\hline $\mathbf{3}$ & 65 & 57,5 & 47,5 & 42,5 & 40 \\
\hline $\mathbf{4}$ & 52,5 & 47,5 & 25 & 35 & 37,5 \\
\hline $\mathbf{5}$ & 42,5 & 37,5 & 30 & 22,5 & 30 \\
\hline $\mathbf{6}$ & 40 & 35 & 27,5 & 25 & 25 \\
\hline $\mathbf{7}$ & 40 & 27,5 & 35 & 32,5 & 32,5 \\
\hline
\end{tabular}

Dari Tabel 9 dengan menggunakan euclidean distance diperoleh nilai maksimum 65\% pada wavelet level 3 dan $\mathrm{k}=1$.

Tabel 10. Tingkat Akurasi Algoritma KNN Ciri Statistik Variance Dengan Correlation Distance

\begin{tabular}{|c|c|c|c|c|c|}
\hline \multicolumn{7}{|c|}{ Correlation } \\
\hline Wavelet & \multicolumn{5}{|c|}{ K } \\
\cline { 2 - 6 } Level & $\mathbf{1}$ & $\mathbf{3}$ & $\mathbf{5}$ & $\mathbf{7}$ & $\mathbf{9}$ \\
\hline $\mathbf{1}$ & 55 & 50 & 50 & 57,5 & 55 \\
\hline $\mathbf{2}$ & 52,5 & 45 & 47,5 & 47,5 & 45 \\
\hline $\mathbf{3}$ & 57,5 & 62,5 & 50 & 47,5 & 47,5 \\
\hline $\mathbf{4}$ & 57,5 & 37,5 & 20 & 40 & 32,5 \\
\hline $\mathbf{5}$ & 35 & 30 & 35 & 32,5 & 32,5 \\
\hline $\mathbf{6}$ & 42,5 & 40 & 32,5 & 30 & 37,5 \\
\hline $\mathbf{7}$ & 32,5 & 32,5 & 37,5 & 32,5 & 35 \\
\hline
\end{tabular}

Dari Tabel 10 dengan menggunakan euclidean distance diperoleh nilai maksimum $62.5 \%$ pada wavelet level 3 dan $\mathrm{k}=3$.

\subsection{Analisis Perbandingan Algoritma SVM dan KNN}

Dari 160 data uji citra fundus untuk klasisfikasi DR berdasarkan tingkat keparahannya (mild, severe, dan moderate) dan normal, dilakukan pengujian. Adapun skenario pengujiannya adalah sebagai berikut :

I. Pengujian dengan algoritma SVM One Versus One (OVO)dan One Versus All (OVA), masing-masing metoda diujikan dengan menggunakan ciri statistik mean dan variance serta haar wavelet lavel $1-7$. 
Dari kedua ciri statistik tersebut (mean dan variance) diperoleh tingkat akurasi maksimum $62 \%$ untuk SVM dengan metoda One Versus All seperti yang diperlihatkan pada Gambar 14.

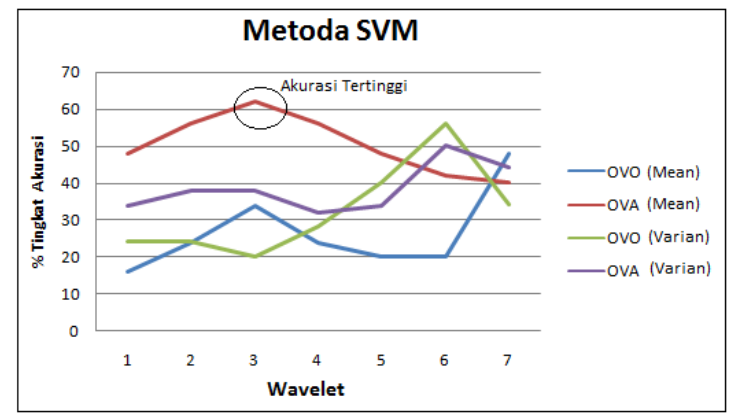

Gambar 14. Grafik akurasi algoritma SVM

II. Pengujian dengan algoritma KNN dengan algoritma distance yang digunakan adalah cosine, cityblock, euclidean, dan correlation. Sama halnya seperti pada pengujian dengan algoritma SVM, pada algoritma KNN dengan masing-masing distance diujikan dengan menggunakan ciri statistik mean dan variance serta haar wavelet lavel $1-7$.

Dari hasil pengujian dengan algoritma KNN menggunakan ciri statistik mean dengan metode cosine distance, cityblock distance, euclidean distance, dan correlation distance diperoleh nilai akurasi maksimum $65 \%$ dengan $\mathrm{K}=9$ metoda cityblok distance pada wavelet level $=1$ seperti yang ditunjukkan pada gambar 15 . Sedangkan pengujian dengan ciri statistik variance diperoleh nilai akurasi maksimum $65 \%$ dengan metode cosine distance, cityblock distance, euclidean distance, dan $62.5 \%$ dengan metode correlation distance. Seperti yang ditunjukkan pada gambar 16, nilai akurasi maksimum $65 \%$ diperoleh secara mayor pada wavelet level 3 dan $\mathrm{k}=1$.

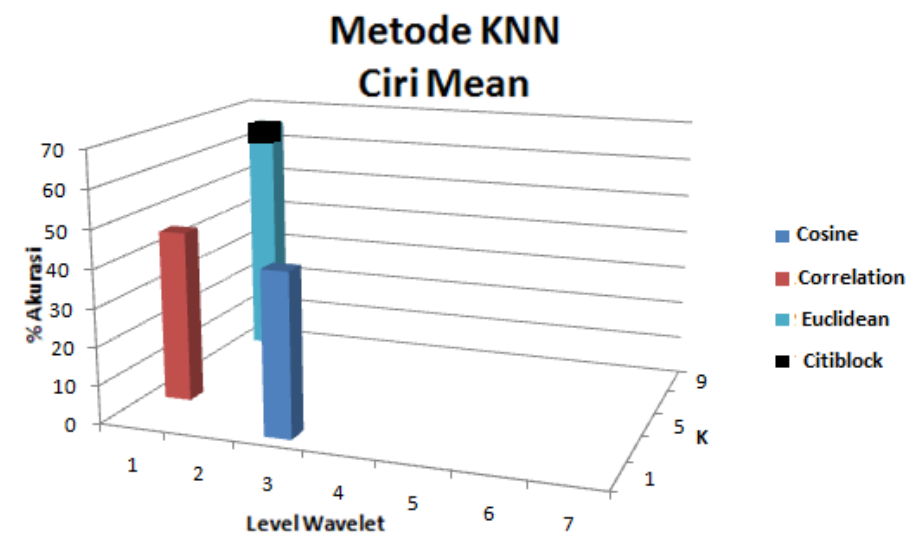

Gambar 15. Grafik akurasi algoritma KNN dengan ciri statistik mean 


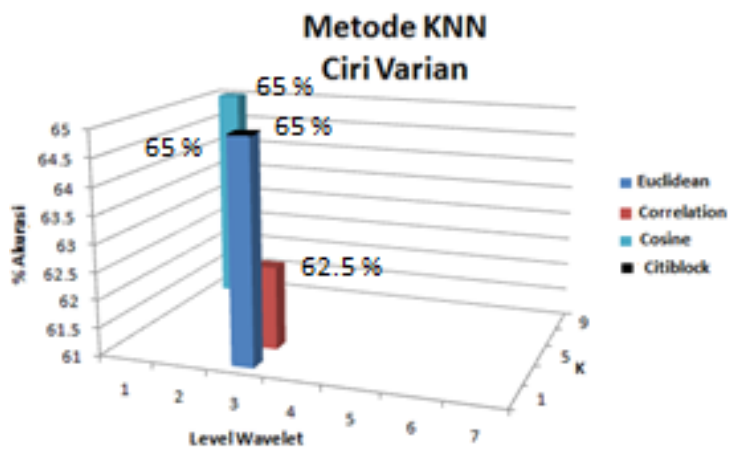

\section{Gambar 16. Grafik akurasi algoritma KNN dengan ciri statistik variance}

Berdasarkan Gambar 14,15 dan 16 dapat dilihat bahwa tingkat akurasi maksimum untuk klasifikasi tingkat keparahan penyakit DR dengan algoritma SVM dan KNN adalah $62 \%$ dan $65 \%$. Tingkat akurasi SVM diperoleh $62 \%$ dengan menggunakan metode One Versus All melalui pendekatan algoritma kernel dan parameter haarwavelet pada level 3, serta ciri statistik yang digunakan adalah mean. Performansi KNN pada kasus ini, lebih baik dibandingkan dengan SVM. Pada KNN tingkat akurasi $65 \%$ diperoleh relatif stabil pada $\mathrm{K}=$ 9 untuk ciri statistik mean dan $\mathrm{K}=1$ untuk ciri statistik variace (berkebalikan). Selain nilai K, parameter algoritma distance yang digunakanpun mempengaruhi. Dari hasi pengujian untuk kedua metode ciri statistik, cityblock distante memperoleh nilai akurasi yang sama dan maksimum yaitu $65 \%$.

\section{KESIMPULAN}

Penelitian ini mempresentasikan suatu perbandingan antara algoritma SVM dan KNN sebagai classifiers tingkat keparahan penyakit Diabetic Retinopati (DR) berdasarkan eksudat dan mikroaneurisma yang terdiri dari 60 citra latih dan 160 citra uji dari citra fundus RS. Cicendo Bandung. Klasifikasi DR yang diamati pada penelitian ini adalah kelas mild,moderate, dan severe. Adapun hasil yang diperoleh sebagai berikut :

1. Klasisfikasi dengan algoritma SVM diperoleh tingkat akurasi maksimum $62 \%$ dengan metoda OVA ciri statistik mean.

2. Klasisfikasi dengan algoritma KNN diperoleh nilai akurasi maksimum $65 \%$ dengan $\mathrm{K}=9$ metoda cityblok distance pada wavelet level $=1$, ciri statistik mean dan variance.

\section{DAFTAR PUSTAKA}

Zahara, Haula Siva. (2011). Simulasi Untuk Klasifikasi Retinopati Diabetes Nonproliferatif Berdasarkan Mikroaneurisma dan Hemorrhages : Fakultas Elektro Dan Komunikasi. Institut Teknologi Telkom.

Riliandi, Gladi Yudha. (2013). Deteksi diabetes melali citra retina dengan menggunakan Transformasi wavelet dan learning vector quantization : Institut Teknologi Telkom.

Rajpoot, K, M., and Rajpoot, N, M.,(2004). Wavelets and Support Vector Machines for Texture Classification : Proceedings of INMIC.

Tjandrasa, H., Eka Putra, R., Wijaya, A., Arieshanti, I., (2013). Classification of NonPoliferative Diabetic Retinopathy Based on hard Exudates Using Soft Margin SVM. Malaysia: IEEE International Conference on Control System, Computing and Engineering. 
Santosa, Budi. (2005).Tutorial Vector Machine : Fakultas Teknik Industri.Institut Teknologi Surabaya.

Cristianini, N., and Shawe-Taylor, J.,( 2000). An Introduction to Support Vector Machines : Cambridge University Press.

Sudha, L. P., and Bhavani, R., (2012). Gait Base Gender Identification Using Statistical Pattern Classifiers : International Journal of Computer Application (0975-8887), Vol.40,No. 8.

Antal, B., Hajdu, A., 2012. An Ensemble-Base system for Microaneurysm Detection and Diabetic Retinopathy Grading : IEEE Transaction on biomedical engineering, Vol. 59, No. 6.

Gitasari, Ratna Ayu. 2015.Klasifikasi Penyakit Diabetes Retinopati Berdasarkan Citra Digital Dengan Menggunakan Metode Wavelet dan Support Vector Machine :Fakultas Teknik Elektro. Universitas Telkom.

Kerami, D., dan Murfi, H., 2004. Kajian Kemampuan Generalisasi Support Vector Machine Dalam Pengenalan Jenis Splice Pada Barisan DNA : Makara Sains, Vol. 8, No. 3, 89-95.

Vaughan DG, Asbury T, Eva PR. 2000. Oftalmologi Umum. Edisi ke-14. Jakarta: Widya Medika.211-4. 